\title{
An example of secondary fault activity along the North Anatolian Fault on the NE Marmara Sea Shelf, NW Turkey
}

\author{
Huseyin Tur \\ Istanbul University, Engineering Faculty, Geophysics Department, Avcllar, Istanbul, Turkey \\ (Received September 29, 2005; Revised April 12, 2006; Accepted March 24, 2007; Online published June 27, 2007)
}

\begin{abstract}
Seismic data on the NE Marmara Sea Shelf indicate that a NNE-SSW-oriented buried basin and ridge system exist on the sub-marine extension of the Paleozoic Rocks delimited by the northern segment of the North Anatolian Fault (NS-NAF), while seismic and multi-beam bathymetric data imply that four NW-SE-oriented strike-slip faults also exist on the shelf area. Seismic data indicate that NW-SE-oriented strike-slip faults are the youngest structures that dissect the basin-ridge system. One of the NW-SE-oriented faults (F1) is aligned with a rupture of the North Anatolian Fault (NAF) cutting the northern slope of the Çınarcık Basin. This observation indicates that these faults have similar characteristics with the NS-NAF along the Marmara Sea. Therefore, they may have a secondary relation to the NAF since the principle deformation zone of the NAF follows the Marmara Trough in that region. The seismic energy recorded on these secondary faults is much less than that on the NAF in the Marmara Sea. These faults may, however, produce a large earthquake in the long term.
\end{abstract}

Key words: Marmara Sea Shelf, North Anatolian Fault (NAF), secondary fault activity.

\section{Introduction}

The North Anatolian Fault (NAF) is located in the northern part of the Anatolian Block lying roughly parallel to the Black Sea coast (Ketin, 1948; Şengör, 1979; Barka and Kadinsky-Cade, 1988; Barka, 1992; Fig. 1(a)). Morphological features of this fault are clearly traceable on land from the Karlova Basin in the east, where it joins with the East Anatolian Fault (EAF), to the Marmara Sea in the west (Fig. 1(a)). The NAF bifurcates into two segments east of the Marmara Sea. The northern segment of the North Anatolian Fault (NS-NAF) passes through the Marmara Sea, dissecting the E-W-trended elliptic basin, the Marmara Trough (Fig. 1(b), 2). Seismological studies indicate that the NS-NAF is the most active segment in the Marmara Sea (Gürbüz et al., 2000; Pınar et al., 2003), as evidenced by the great earthquake in the Marmara Sea (Kocaeli Earthquake, İzmit Gulf, $M=7.4$ ). Recent studies indicate that the next great earthquake may occur at the eastern portion of the Marmara Sea, off İstanbul (Barka, 1999; Armijo et al., 2005). As a result, scientists are recognizing the great importance of the part of the Marmara Sea in terms furthering our knowledge on fault activity and earthquake hazard.

The Marmara Trough consists of four sub-basins, called the Çınarcık, Silivri, Central, and Tekirdağ basins; these are separated by the three sub-ridges, called the Eastern, Central, and Western sub-ridges, which run from east to west, respectively (Fig. 1(b)). Since this morphology is thought to have formed by the activity of the NS-NAF, several origins for the Marmara Trough have been proposed, which

Copyright (c) The Society of Geomagnetism and Earth, Planetary and Space Sciences (SGEPSS); The Seismological Society of Japan; The Volcanological Society of Japan; The Geodetic Society of Japan; The Japanese Society for Planetary Sciences; TERRAPUB. include a graben system, pull-apart basins, and basin generation by a trans-tensional fault or by a transform-transformtransform type triple junction (Ketin, 1968; Barka and Kadinsky-Cade, 1988; Barka, 1992; Smith et al., 1995; Armijo et al., 1999, 2002, 2005; Okay et al., 1999, 2000; Aksu et al., 2000; Yaltırak, 2002; Carton, 2003). Most of these studies postulated that the northern shelf and the hinterland area (i.e., Thrace, İstanbul, and Kocaeli Peninsulas; Fig. 1(a), (b)) are located on the "foot-wall" of the Marmara Trough and, therefore, no or limited individual fault activity may have occurred on the "foot-wall" during the present tectonic period in the Marmara Sea.

In contrast, results from other studies in which detailed multi-beam bathymetric and seismic data were obtained by the Turkish Navy, Department of Navigation, Hydrography and Oceanography and the General Directorate for Mineral Research and Exploration of Turkey have suggested that the NS-NAF cuts the basins and ridges of the Marmara Trough in an unconforming manner instead of forming them (İmren et al., 2001; Le Pichon et al., 2001; Gökaşan et al., 2001, 2002, 2003; Gazioğlu et al., 2002; Kuşçu et al., 2002; Demirbağ et al., 2003; Rangin et al., 2004; Şengör et al., 2004; Fig. 2). According to this theory, the Marmara Trough originated as an extensional basin in the Late Miocene, which then collapsed with the initiation of the NS-NAF (Gökaşan et al., 2003). Gazioğlu et al. (2002) observed two different types of slope morphologythe high-angle linear and low-angle curved slopes, both bordering the Marmara Trough (Fig. 3(a), (b)). These also authors emphasized that the NW-SE-oriented high-angle linear northern slope of the Çınarcık Basin, which is the southern boundary of the shelf area and the area focused on in the present study, represents the rejuvenated part of older low-angle, curved slopes that developed during the collapse 


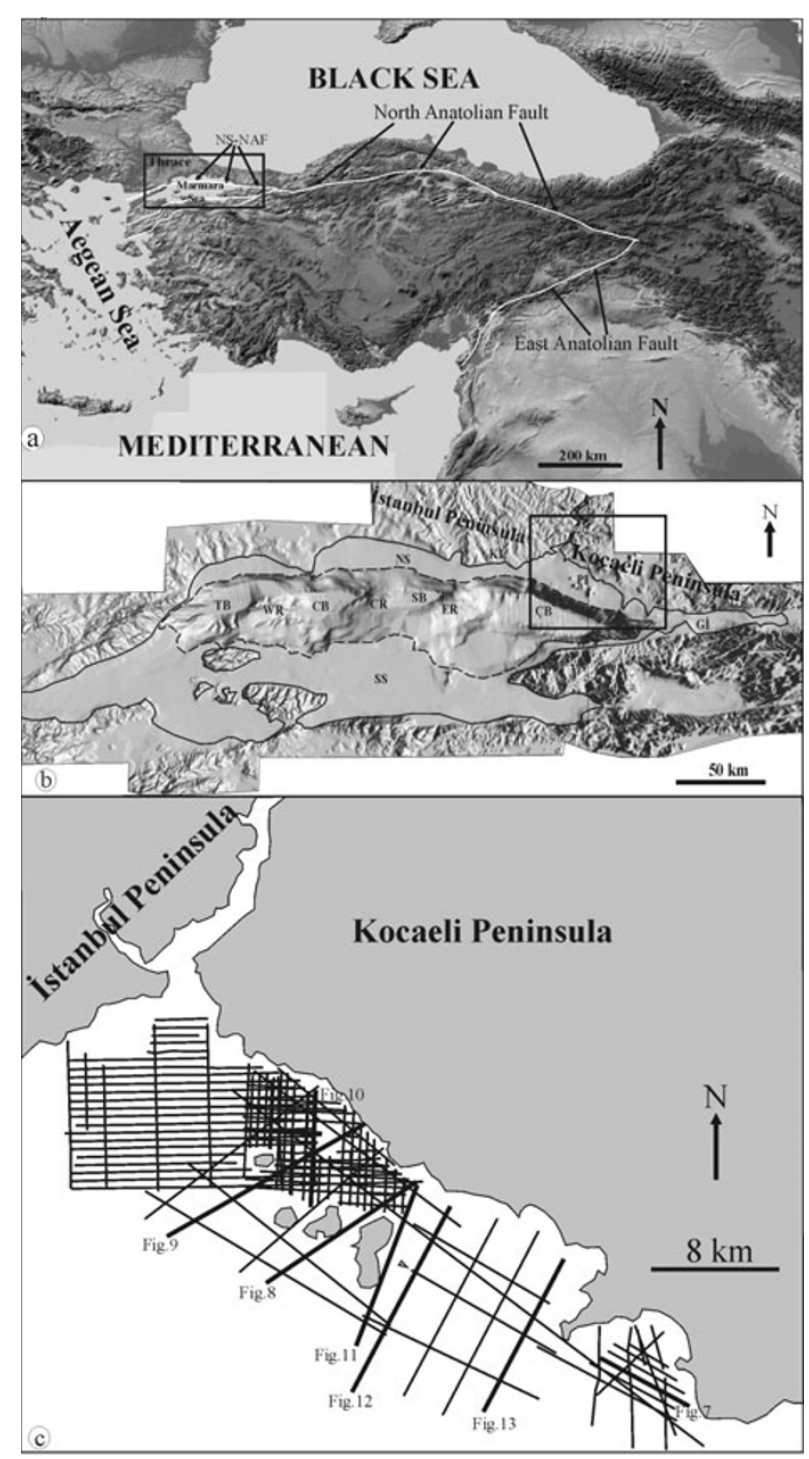

Fig. 1. (a) Location map illustrating the North Anatolian and East Anatolian faults, and the study area; (b) Three-dimensional ERDAS image of the Marmara region (modified from Gazioglu et al., 2002). $A P=$ Armutlu Peninsula, $C B=$ Central Basin, $C ̧ B=$ Çınarcık Basin, ER=Eastern Ridge, Gİ=İzmit Gulf, $\mathrm{KL}=$ Küçükçekmece Lagoon, NS=Northern Shelf, $\mathrm{PI}=$ Prince Islands, $\mathrm{SB}=$ Silivri Basin, Soİ=Strait of İstanbul (Bosphorus), $\mathrm{SS}=$ Southern Shelf, $\mathrm{TB}=$ Tekirdağ Basin, $\mathrm{WR}=$ Western Ridge, $\mathrm{CR}=$ Central Ridge. Dashed line indicates the boundary of the Marmara Trough. (c) Detailed location maps of the study area and seismic profiles.

phase of the Marmara Sea Basin. Fault plane solutions of aftershocks of the earthquake on 17 August 1999 revealed a pure strike-slip on this slope (Örgülü and Aktar, 2001). This fault is contiguous towards the İstanbul Peninsula where NW-SE-directed strike-slip faults are present along the northern shelf, as evidenced by high-resolution seismic data on the northern shelf off Avcrlar town, which was extensively damaged by the 1999 earthquake, and the Istanbul Peninsula (Fig. 4; Gökaşan et al., 2002). Gökaşan et al. (2002) suggested that these faults constitute the NW extension of the NAF along the northern slope of the Çinarcik Basin, a proposal supported by the existence of some NWSE-directed faults cross-cutting the northern slope of the Çınarcık Basin (Gökaşan et al., 2003) on the reflectivity

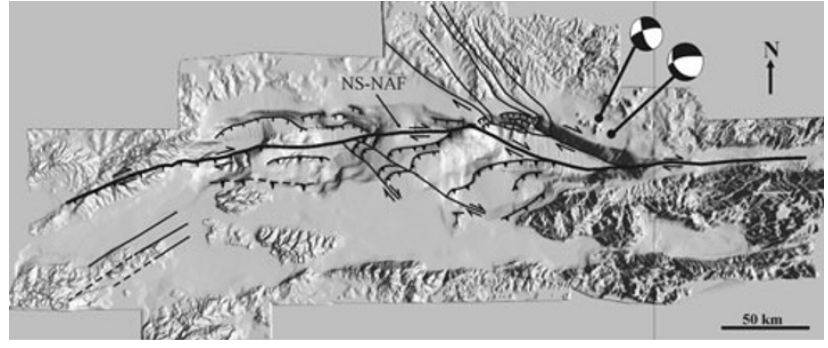

Fig. 2. Fault map of the Marmara Sea, based on multi-beam bathymetric and seismic data (Modified from Gökaşan et al., 2003). The bold line shows the NS-NAF. Two epicenters around the Prince Islands taken from Pinar et al. (2003) indicate earthquake events on the NE shelf of the Marmara Sea.

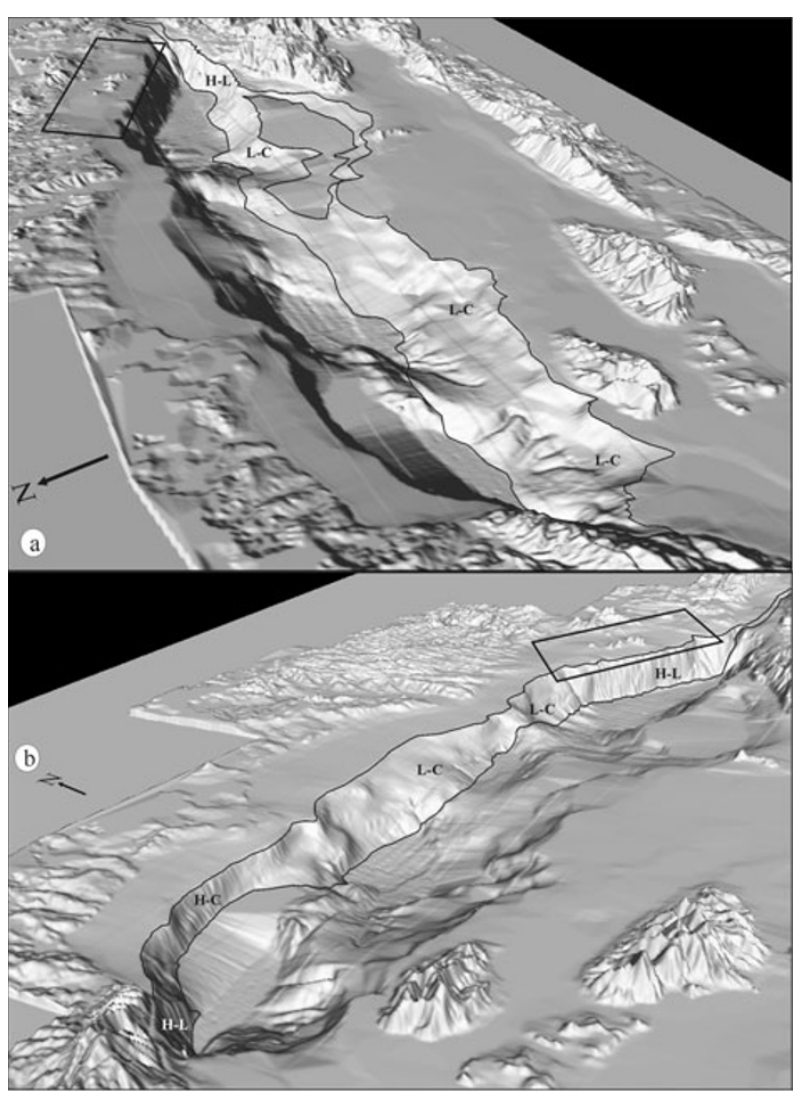

Fig. 3. 3D images showing the shelves and slope boundaries (modified from Gazioglu et al., 2002). (a) Southern shelf and slope; (b) Northern shelf and slope. Lines indicate the slope boundaries. See text for explanation. $\mathrm{H}-\mathrm{L}=$ High-angle linear slope, $\mathrm{L}-\mathrm{C}=$ Low-angle curve slope.

map of the Çinarcık Basin (published by Le Pichon et al., 2001) and by the earthquakes which have occurred recently on the northern shelf area (Pinar et al., 2003; Fig. 2). Therefore, some of the recent studies using the multi-beam bathymetric data from the Marmara Sea suggest that NS-NAF passes through the Marmara Sea as a strike-slip fault rather than as a normal fault.

Oktay et al. (2002) suggested the presence of a NNESSW-trending, left-lateral strike-slip fault zone between the clockwise-rotated İstanbul and Kocaeli Peninsulas. This left lateral fault zone was thought to have been formed by the activity of the NS-NAF, which led to formation of the Strait of İstanbul. These recent studies indicate that the 


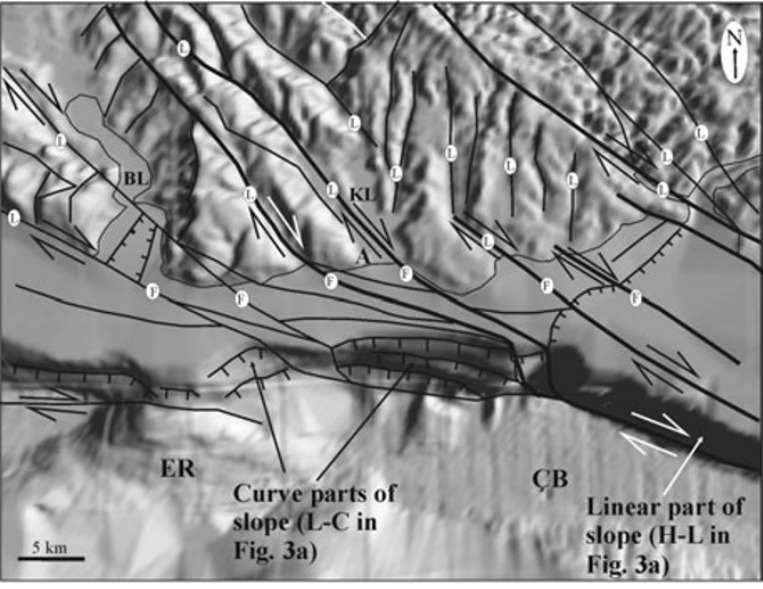

Fig. 4. Faults (F) cutting the sea floor of the shelf area from the Strait of İstanbul Canyon to Büyükçekmece Lagoon and lineaments on land (L) aligning with the faults (modified from Gökaşan et al., 2002), $\mathrm{A}=$ Avcılar Town, $\mathrm{BL}=$ Büyükçekmece Lagoon, $\mathrm{KL}=$ Küçükçekmece Lagoon, $\mathrm{CB}=$ Çınarcık Basin, ER=Eastern Ridge.

secondary faults around the principle deformation zone in the Marmara Sea (NS-NAF) may have played an important role in the formation of the morphological features and local earthquakes in this area (Gökaşan et al., 1997; Demirbağ et al., 1999; Oktay et al., 2002; Gökaşan et al., 2002, 2003; Pinar et al., 2003).

In the study reported here, the NE shelf area of the Marmara Sea between the City of Istanbul and the NAF in the Çinarcık Basin was investigated by means of highresolution seismic and multi-beam bathymetric data with the aim of tracing any secondary fault activity in the north of the NS-NAF and explaining the relationship between the secondary faults and the principle fault zone.

\section{Material and Methods}

The seismic data (Fig. 1(c)) were collected by the Turkish Navy, Department of Navigation, Hydrography and Oceanography (TN-DNHO) using a single-channel Uniboom analogue seismic system. An analogue recorder runs at 100- to 400-ms scan lengths. A paleo-topographic map illustrating the upper surface of the basement and a sedimentthickness map of the basin deposits were prepared for this study using these seismic data (Fig. 5, inset A of Fig. 5). The depth of the basement and the thickness of the basin deposits were calculated using velocities of $1500 \mathrm{~m} / \mathrm{s}$ for seawater and an average of $2000 \mathrm{~m} / \mathrm{s}$ for the basin deposits; this latter value was previously obtained as the average velocity of the Plio-Quaternary channel deposits of the Strait of İstanbul (Uluğ et al., 1987). Multi-beam bathymetric data (Fig. 5(a), (b)) were also collected by TN-DNHO using an Elac Bcc MK-2 Multibeam Echosounder, which operates with 126 beams at $180 \mathrm{kHz}$. The Differential Global Positioning System (DGPS) was used for the positioning of the vessel.

\subsection{Morphology of the study area}

The morphology of the terrestrial area around the Marmara Sea, including the İstanbul and Kocaeli Peninsulas, is dominantly implied by a mature horizontal erosional surface that developed during the Upper Miocene-Pliocene pe-

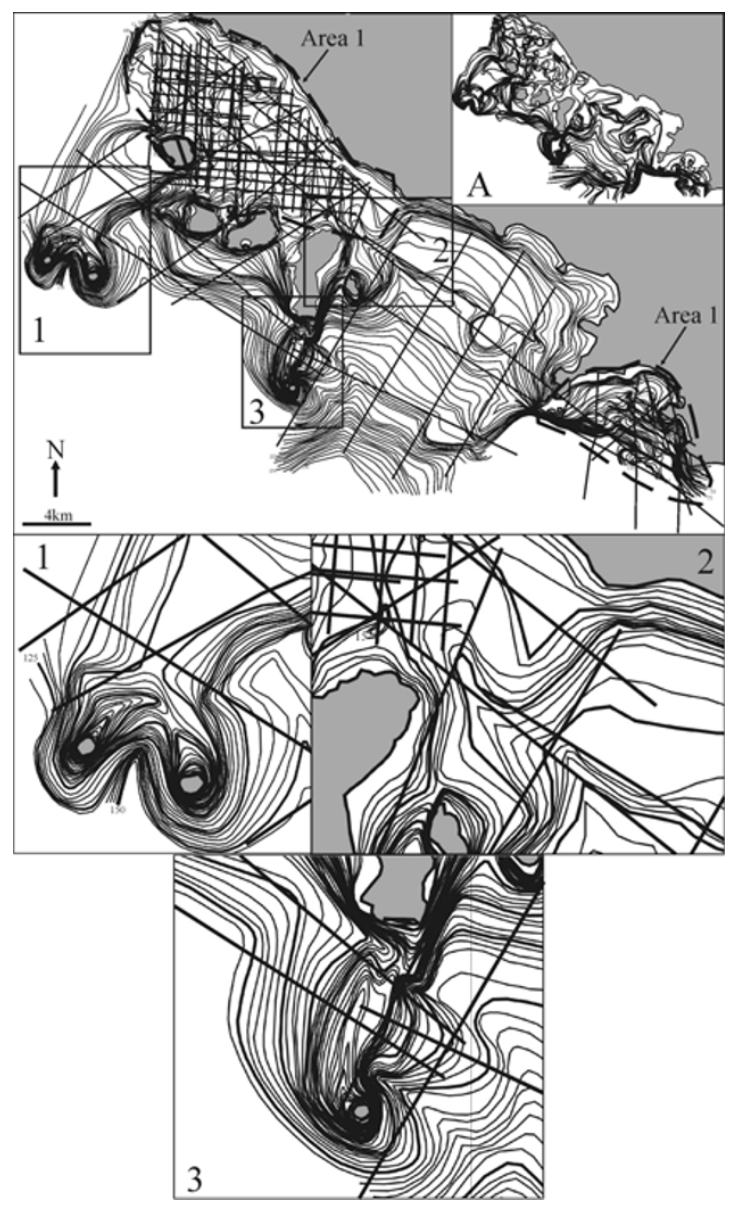

Fig. 5. Paleo-topography map of basement upper surface and seismic profiles. Bold lines indicate the profiles showing in this study. Number of the profiles gives way to prepare this map in detail at the area between Prince Islands and Kocaeli Peninsula, and the area in the Tuzla Bay (Area 1). In addition, some key areas illustrated on insets 1-3 have enough seismic data for understanding the relationship between NNE-SSW and NW-SE-oriented lineaments (see Fig. 15 for explanation). On the rest of the area, Paleo-topography gives only general trend of the basement upper surface. Inset A illustrates sediment thickness of the study area. Depths and thickness of contours are in meters.

riod (Cvijic, 1908; Pamir, 1938; Perinçek, 1991; Emre et al., 1998; Gökaşan et al., 1997; Erinç, 2000; Elmas, 2003; Yiğitbaş et al., 2004; Yılmaz, 2006; Gökaşan et al., 2005a). Fragments of this surface are still traceable at different elevations along the area. This erosional surface was rejuvenated by tectonic activities and sea level fluctuations during the Quaternary period when some parts of the mature erosional surface were lowered by faults to became the base level for deposition, while other parts were elevated (Emre et al., 1998; Demirbağ et al., 1999; Yaltırak et al., 2002). One of the depressional areas developed in this period is the Strait of İstanbul (Alavi et al., 1989; Gökaşan et al., 1997, 2005a, b; Demirbağ et al., 1999; Oktay et al., 2002; Fig. 6(a)). The Strait of Istanbul consists of linear channel fragments in the NE-SW, NW-SE, and N-S directions. Previous studies suggested that coastlines of the strait were controlled by faults (Alavi et al., 1989; Gökaşan et al., 1997; 2005a; Demirbağ et al., 1999; Oktay et al., 2002). Lineaments in similar directions were observed around the Strait of İstanbul (Eroskay and Kale, 1986; Gökaşan et al., 


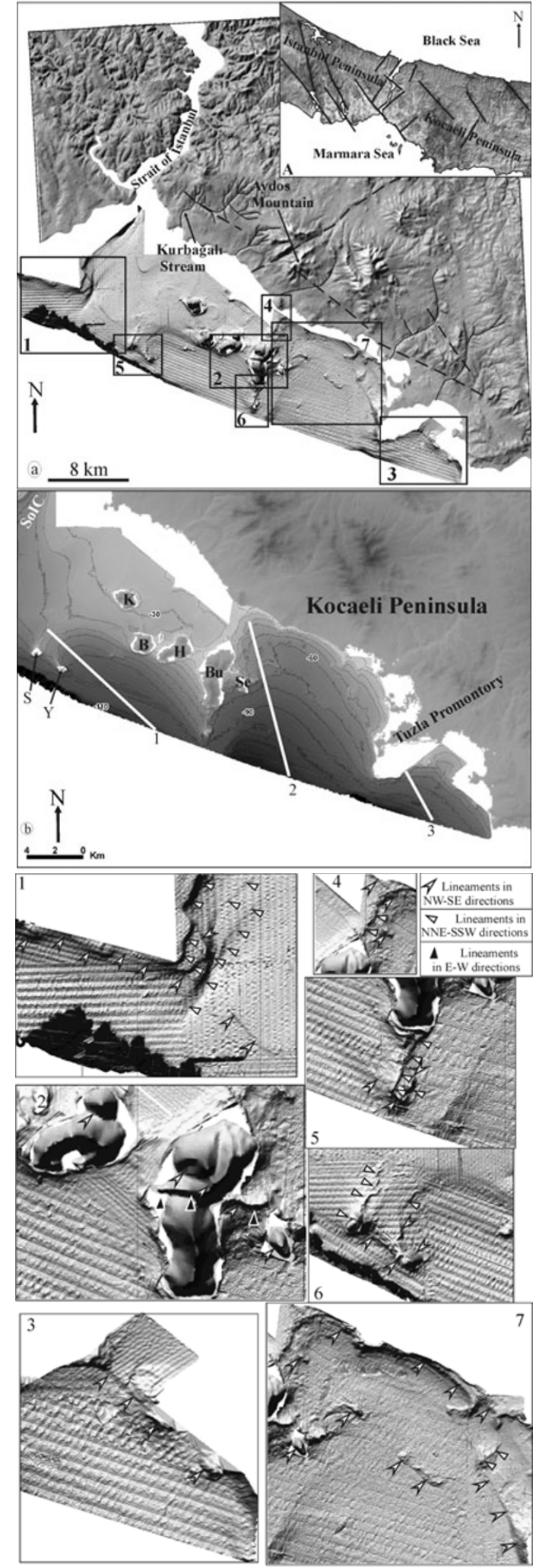

Fig. 6. (a) Digital elevation model of the study area. Squires indicate inset maps (1-7) for detail morphological interpretation of lineaments on the sea floor. Solid and dashed lines on land indicate rivers and lineaments, respectively. Inset A illustrates the general trend of lineaments on the İstanbul and Kocaeli peninsulas. (b) Contour map of the sea floor. Depths of contours are in meters. Three lineaments (1-3) are implied by the long axes of elliptic depressions on the sea floor. $\mathrm{Bu}=$ Büyükada Island, $\mathrm{H}=$ Heybeli Island, $\mathrm{B}=$ Burgaz Island, $\mathrm{K}=$ Kınalı Island, $\mathrm{Se}=$ Sedef Island, $\mathrm{S}=$ Sivri Island, $\mathrm{Y}=$ Yassı Island, $\mathrm{SoIC}=$ The Strait of İstanbul Canyon.
2002; inset A of Fig. 6(a)). Lineaments oriented in the NW$\mathrm{SE}$ and in NNE-SSW directions are also observed on the Kocaeli Peninsula in this study. Along the southern side of the Kocaeli Peninsula, streams feeding into the Sea of Marmara are right laterally displaced by NW-SE directed lineaments (Fig. 6(a)). The most remarkably displaced of these is the Kurbağalı Stream, which is displaced $1.7 \mathrm{~km}$ (Fig. 6(a)). In addition, a NNE-SSW lineament is drawn taking into consideration a linear creek in the Aydos Mountain and a ridge along a plain.

More lineaments lying in the similar directions are also observed on the sea floor of the study area (Fig. 6(a), (b)). Shelf area consists of an island chain (Prince Islands) and a shelf floor (Fig. 6(a), (b)). Prince Islands are composed of Paleozoic rocks that widely crop out on the Kocaeli Peninsula (Seymen 1995; Oktay et al., 2002). N-S-oriented Büyükada Island is the largest member of the chain. In addition, two small islands, the Yassiada and Sivriada islands, are present at the shelf edge. Detailed multi-beam bathymetric data indicate that the shelf floor consists of three asymmetric concave-shaped depressions and the submarine canyon of the Strait of Istanbul (Fig. 6(a), (b)). The Prince Islands and Tuzla Promontory separate these depressions on the sea floor (Fig. 6(a), (b)). The NW-SE-oriented long axes of these depressions are supposed to be lineaments constituting a system of enechelon along the shelf (Fig. 6(b)). In more detail, lineament fragments in the NW-SE direction on the sea floor morphology prove the existence of the dominant NW-SE-directed lineaments in terms of the morphology of the shelf area (insets 1-7 of Fig. 6(a)). Inset 1 of Fig. 6(a) illustrates the western slope and channel floor of the Strait of the Istanbul Canyon (SoIC) located at the shelf edge. The NNE-SSW-directed western slope of the strait is clearly seen on the sea floor. This slope is interpreted to form a remarkable lineament system in the NNESSW direction on the sea floor (inset 1 of Fig. 6(a)). On the other hand, NW-SE-oriented lineaments cross-cut the western slope and the channel floor of the Strait (inset 1 of Fig. 6(a)). The western extension of this lineament reaches to the Küçükçekmece Lagoon. Lineaments oriented in these two directions are dominantly observed on the shelf area. Linear short creeks on Büyükada and Heybeliada islands and on the southern linear coast of Sedefadasi Island indicate a NW-SE-oriented lineament (inset 2 of Fig. 6(a)). On the same map an E-W-oriented promontory in the center of the Büyükada Island and its eastern submarine extension show an E-W-oriented shorter lineament. Inset 3 of Fig. 6(a) illustrate additional NW-SE-lineaments represented by the NE slope of Tuzla Bay. Along the northern and southern extensions of Büyükada Island and north of the Sivriada and Yassiada islands, NNE-SSW-directed lineaments are indicated by the ridges on the sea floor (insets 4, 5, and 6 of Fig. 6(a)). On the other hand, NWSE-oriented lineaments appear where NNE-directed lineaments are curved (insets 4 and 6) or cut (inset 5). Inset 7 of Fig. 6(a) illustrate more NW-SE- and NNE-SSW-oriented lineaments represented by ridges or slopes on the sea floor. 


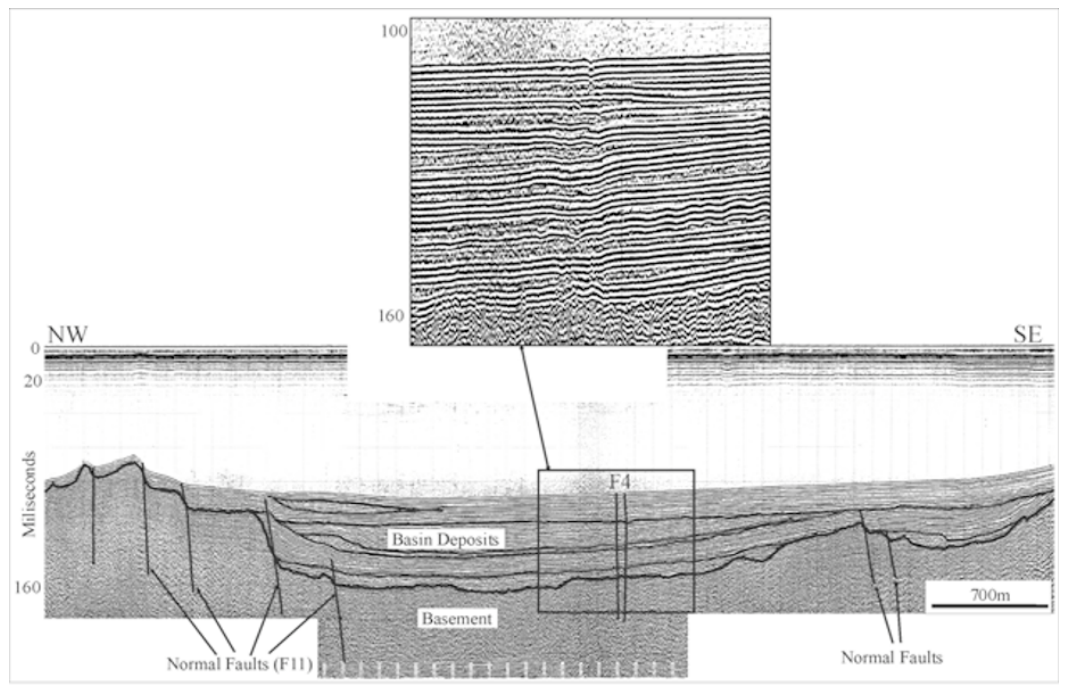

Fig. 7. A seismic profile showing the sedimentary upper (Basin Deposits) and lower (Basement) units and faults F4 and F11 in the Tuzla Bay (see Fig. 1(c) for location).

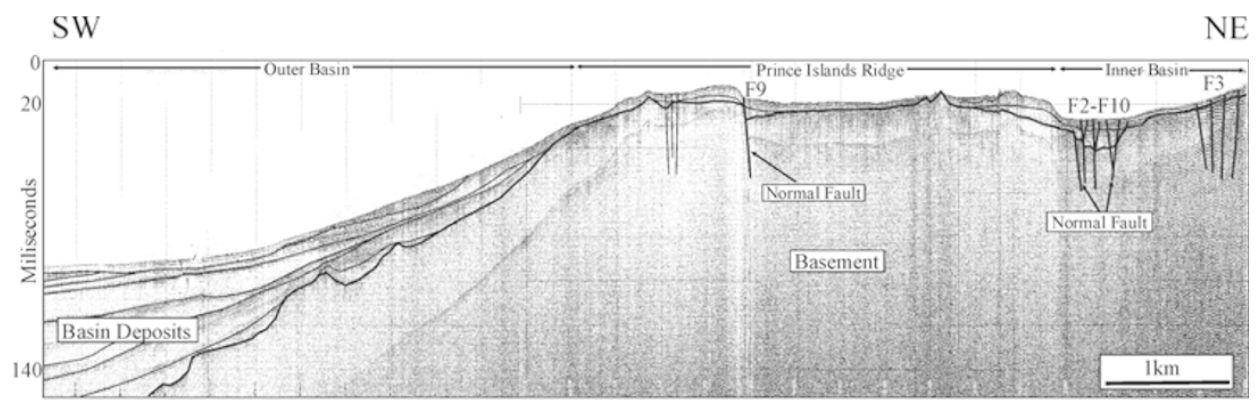

Fig. 8. A seismic profile showing the sedimentary units, Inner and Outer basins, Prince Islands Ridge, and faults F2, F3, F9, and F10 in the study area (see Fig. 1(c) for location).

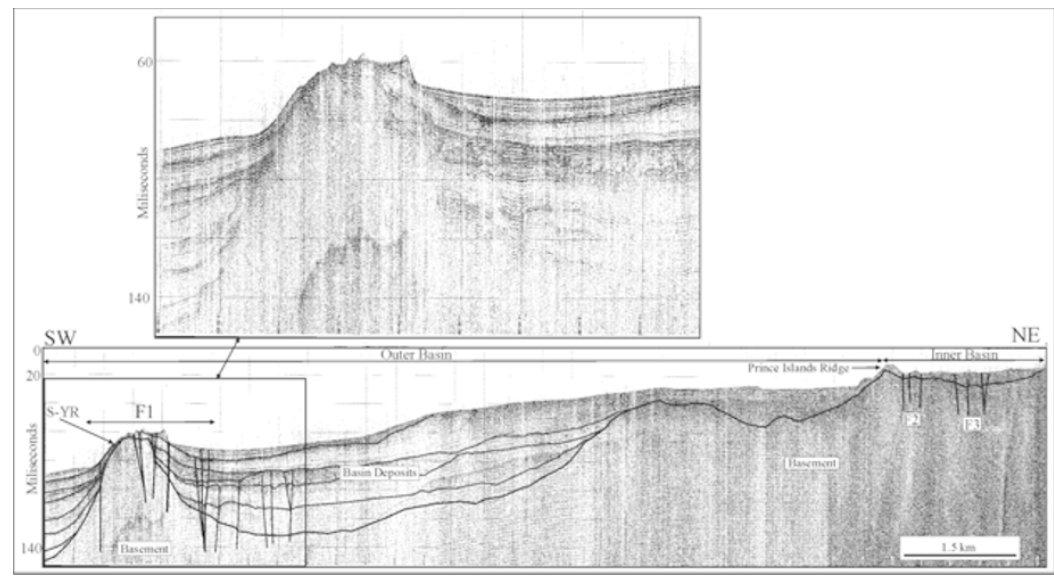

Fig. 9. A seismic profile showing the sedimentary units, Inner and outer basins, Prince Islands Ridge, and faults F1, F2 and F3 at the east of the Strait of İstanbul Canyon. S-YR=Sivri-Yassı Islands Ridge (see Fig. 1(c) for location).

\subsection{Seismic interpretation}

2.2.1 Seismic stratigraphy and basement paleotopography Two different units are clearly distinguishable on high-resolution seismic profiles; these can be classified as the upper and lower units respectively (Fig. 7). The upper unit overlies unconformably a high-amplitude continuous reflection surface that separates the upper unit from the lower. The upper sequence consists of several parase- quence sets (PS) distinguished by erosional unconformity or correlated conformity surfaces (Fig. 7). PS have continuous parallel reflections terminating on each other and on the high-amplitude reflection surface with onlap and downlap indicating the upper unit is composed of basin deposits (Figs. 7-13). The thickness of the basin deposits increases towards the shelf edge and, in some local depressions, along the shelf where the high-amplitude surfaces deepen. The 


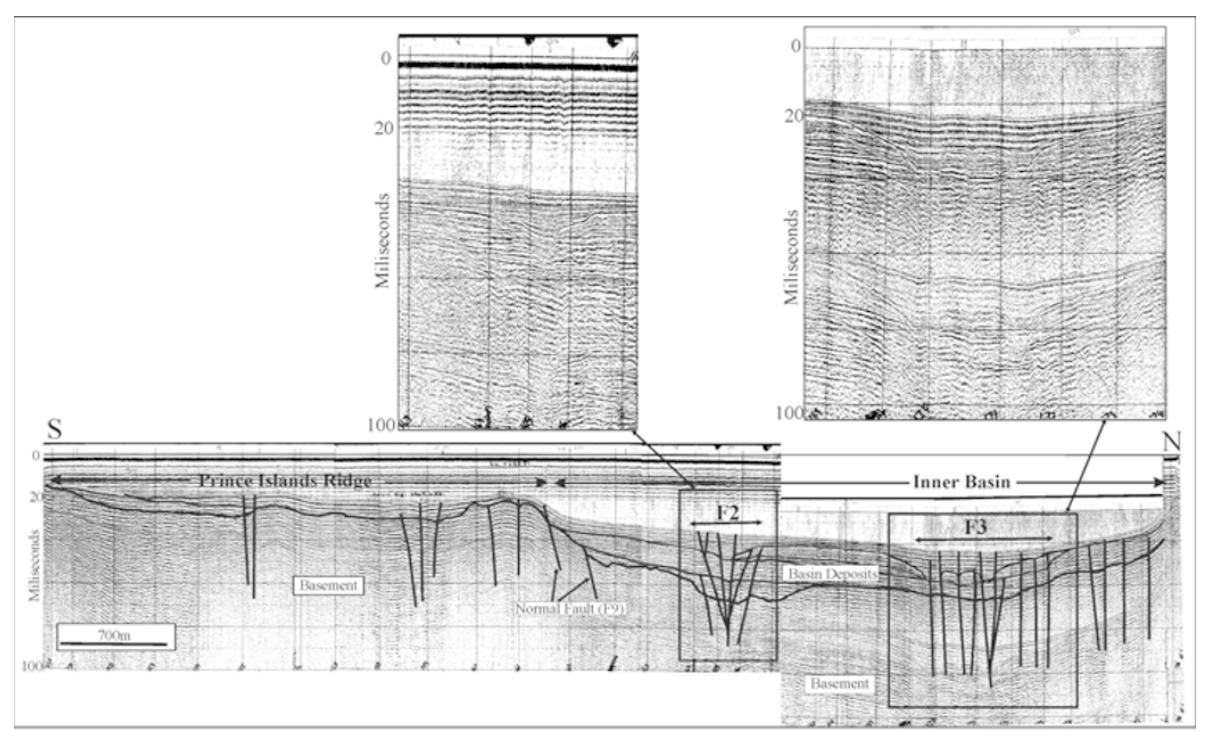

Fig. 10. A seismic profile showing the sedimentary units, Inner Basin, Prince Island Ridge, and faults F2, F3, and F9 in the Inner Basin (see Fig. 1(c) for location).

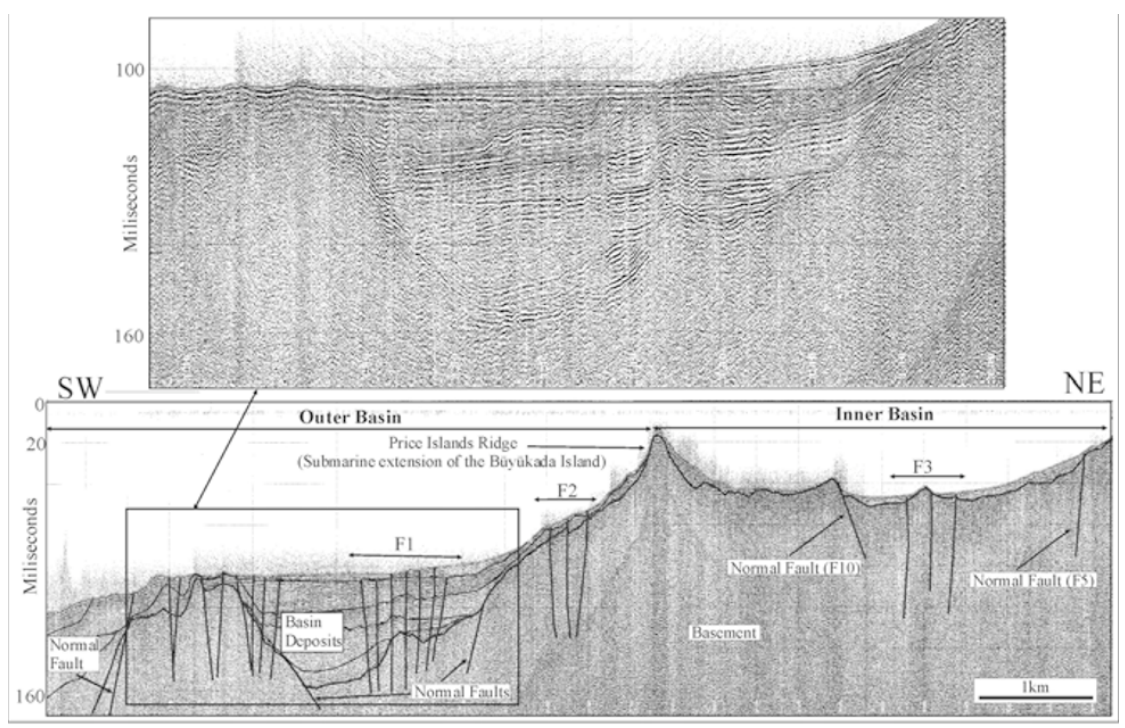

Fig. 11. A seismic profile showing the sedimentary units, Inner and Outer basins, Prince Island Ridge, and faults F1, F2, F3, F5 and F10 to the east of the Büyükada Island (see Fig. 1(c) for location).

reflection configuration of the lower unit is mainly chaotic. The top of this unit constitutes the high-amplitude surface. In general, this surface rises towards the coasts of the Kocaeli Peninsula and Prince Islands (Figs. 7-13), and it possibly intersects with the Paleozoic rocks, which widely crop out on land (Seymen 1995; Oktay et al., 2002). Thus, the lower unit is speculatively interpreted to be the submarine extension of the Paleozoic rocks as previously suggested (Gökaşan et al., 1997; Demirbağ et al., 1999; Oktay et al., 2002). The morphology of the upper surface of this unit, which is represented by the mature erosion surface on land, as explained above, may reveal the evolution of the study area from a mature erosional surface to a depositional area. To this end basement upper surfaces on profiles were correlated, and a basement paleo-topography map was then prepared (Figs. 5, 14). This map primarily shows two basinal areas - the Inner and Outer basins_-separated by the NW-
SE-oriented ridge of the Prince Islands (Figs. 8-13, 14(a), 15). The Prince Islands constitute the subaerial portion of this ridge, with an elevation of up to $200 \mathrm{~m}$. Basement paleo-topography and sediment thickness maps show that the Outer Basin consists of four sub-basins, called the Eastern, Central, Western sub-basins, and the Strait of İstanbul Channel separated by three ridges, called the Eastern, Central, and Western ridges, respectively (Fig. 14(b)). This NNE-SSW-oriented basin-ridge system constitutes a second major morphological feature of the basement paleotopography in the study area. Slopes of these sub-basins are interpreted to be NNE-SSW-oriented lineaments on the basement morphology (Fig. 14(b)). These lineaments are the most remarkable features on the basement paleomorphology. However, NNE-SSW-lineaments are observed to be cut and to be displaced by the NW-SE-oriented lineaments (Fig. 14(c)). These lineaments are represented by the 


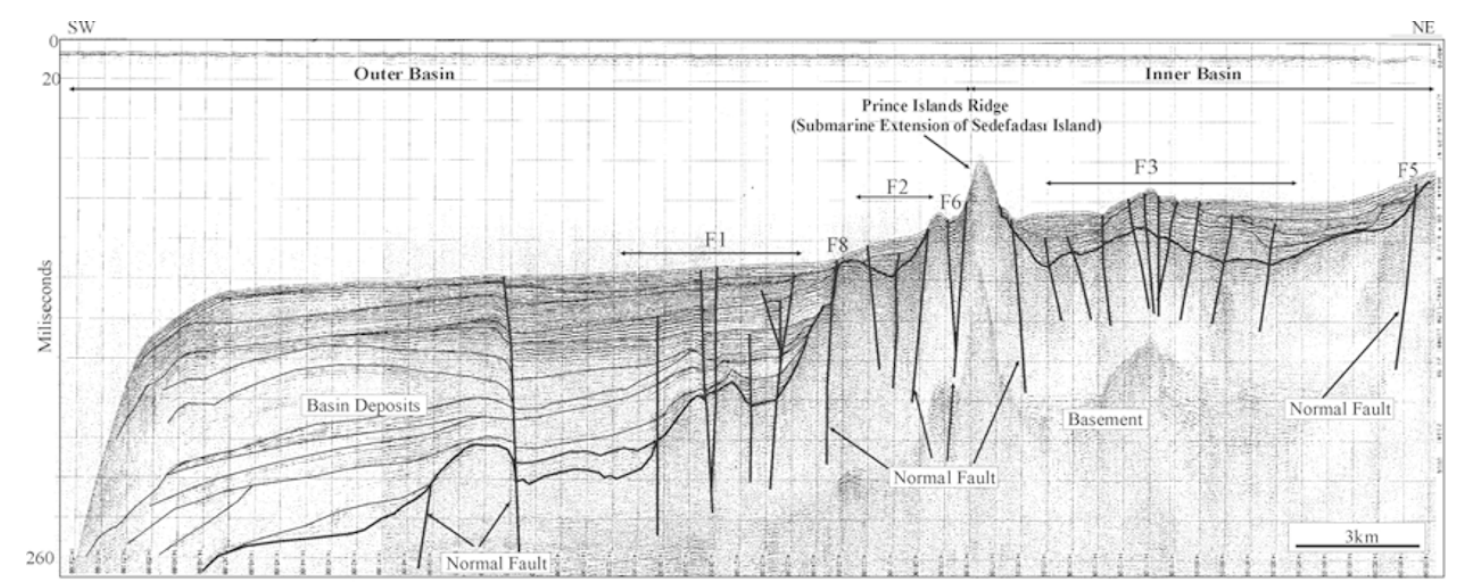

Fig. 12. A seismic profile showing the sedimentary units, Inner and Outer basins, Prince Islands Ridge, and faults F1, F2, F3, F5, F6 and F8 to the east of the Sedefadasi Island (see Fig. 1(c) for location).

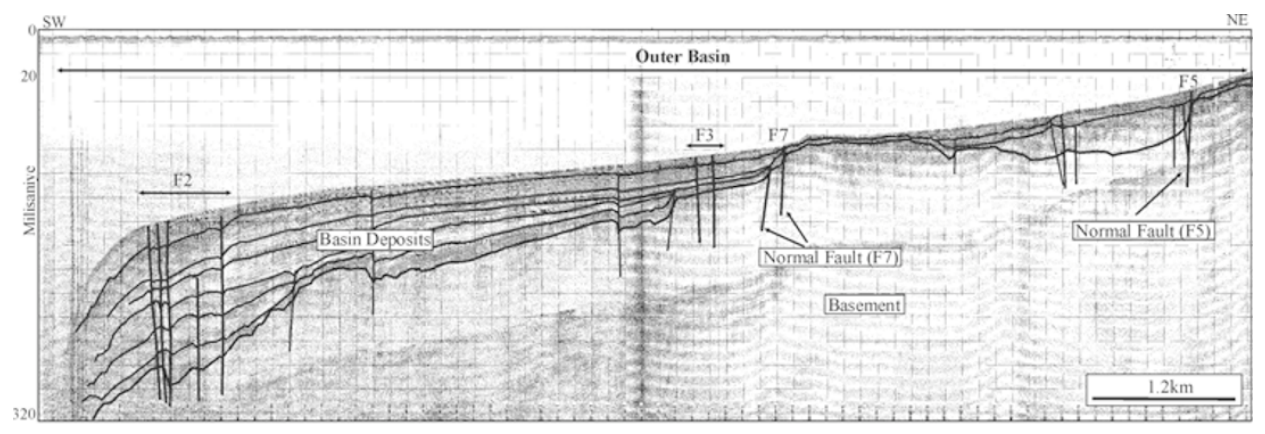

Fig. 13. A seismic profile showing the sedimentary units, Outer Basin, and faults F2, F3, F5 and F7 to the west of the Tuzla Promontory (see Fig. 1(c) for location).

paleo-drainage system and secondary slopes along the Inner Basin (Fig. 14(c)) and may be interpreted to be secondary morphological features in the study area. However, since they cut the slopes of the sub-basins (insets of Fig. 14(c)) and since orientations of the Prince Islands and dominant lineament trends on the sea floor are in the same direction, these lineaments should also be considered to be yet another important feature, in addition to the NNE-SSW features, for studying the evolution of the study area.

2.2.2 Structural interpretation of seismic data Several faults are observed on the seismic data (Fig. 16). Some of these make dip-slip movements at the basement upper surface and form the depressions in the study area, such as the sub-basins in the Outer Basin (Figs. 7, 8, 10-13). The thickness of the basin deposits increases towards these faults, indicating that they are normal faults (Figs. 7, 8, inset of $11,12,13)$. These faults are interpreted to be responsible for forming the sub-basins and ridges in the study area (Fig. 14(b)). Most of the normal faults should have been active during the Plio-Quaternary period since they form the basins of the post-erosional deposits. Some normal faults (F5-F11) affect the sea floor in the study area (Figs. 7, 8, 11-13), although some vertical deformation zones are also observed on profiles. Initial horizontal parallel reflections of the basin deposits are cut along these zones and tilted in different directions. Very little dip-slip movement to form local depressions or ridges on layers is observed along these zones; however, layers on both sides of these zones do not show any meaningful dip-slip movement for interpretation as foot wall or hanging wall of a normal fault. This indicates that the slip directions of these zones may have occurred along the third axis of the profiles. Some of the ruptures are interpreted to merge at depth and form flower structures (Fig. 10). Thus, this evidence may indicate that these are strike slip faults in the study area (Figs. 7-13).

Determination of the directions of the faults observed on each seismic profile is difficult since no 3D seismic data are available for the area. Consequently, sea floor and basement upper surface maps were used to help build up the structural map of the study area. Normal faults are in good agreement with the slopes on the upper surface of the basement and the sea floor (Figs. 6(a), 14(a), 16). Some of these overlap with the NNE-SSW-oriented slopes delimiting the sub-basins on the basement paleo-topography (i.e., faults F6, F7, F8, and F11 in Fig. 16). In addition, the western slope of the Strait of İstanbul (fault F12 in Fig. 16) was also interpreted to be a NNE-SSW-oriented normal fault in an early study (Oktay et al., 2002). The remaining normal faults (faults F5, F9, and F10 in Fig. 16) trend in an NW-SE direction, as clearly revealed by the morphology of the sea floor. On the other hand, strike-slip faults observed on the seismic profiles located towards the NW-SEoriented lineaments on the sea floor form an en echelon system on the shelf area (Figs. 6(b), 16). These faults are also in good agreement with the NW-SE-oriented lineaments on the basement morphology dissecting the slopes of the sub- 

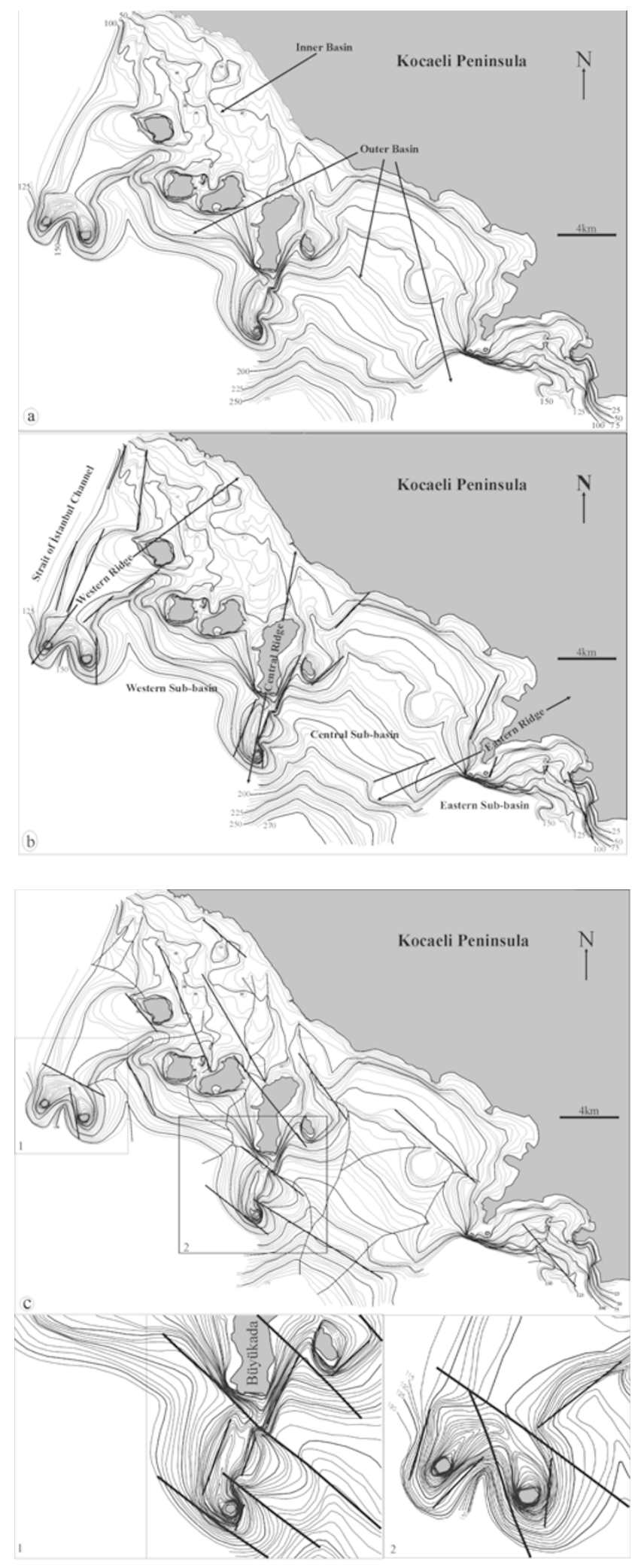

Fig. 14. (a) Peleo-topography of the Paleozoic Rocks upper surface. (b) NNE-SSW-oriented sub-basins (Western, Central and Eastern sub-basins, and Strait of Istanbul Canyon), and ridges (Western, Central, and Eastern ridges) in the Outer Basin are clearly seen on this map. NNE-SSW-oriented lineaments are indicated by the slopes of the sub-basins. (c) NW-SE-oriented lineaments indicated by discontinuances and displacements on NNE-SSW-oriented slopes of the sub-basins. Insets 1 and 2 illustrate two key areas used for explaning the relationship between two different oriented lineament series.

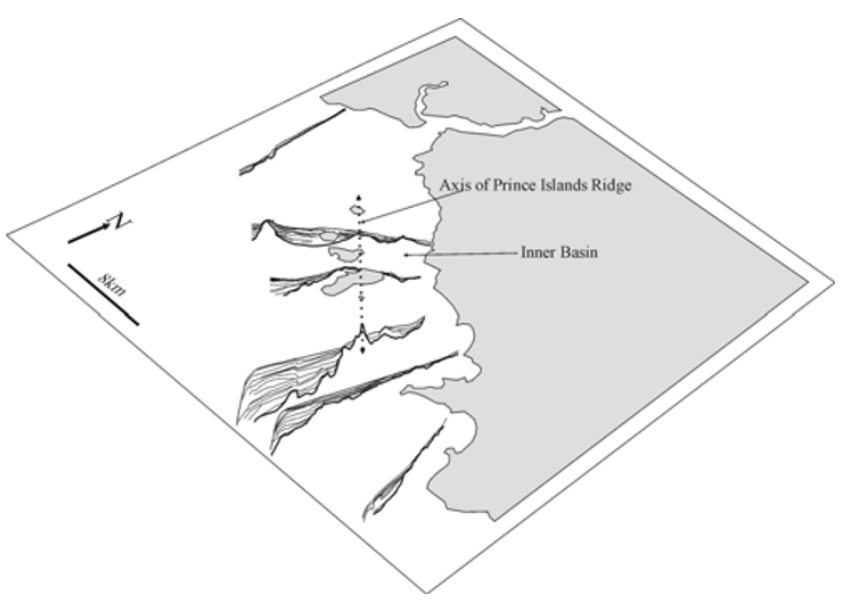

Fig. 15. Projections of seismic profiles in the study area. General trend of the Prince Island is in a NW-SE direction.

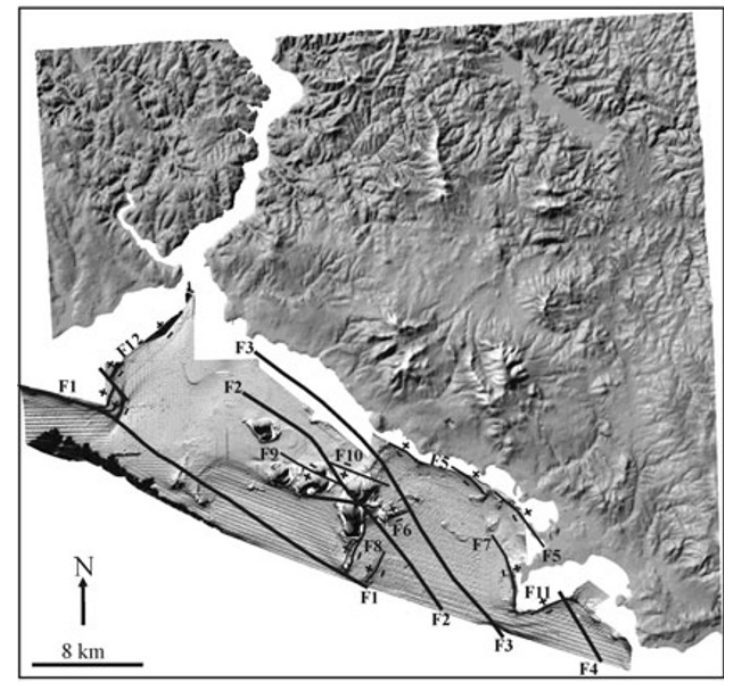

Fig. 16. Faults cutting the basin deposits and the sea floor in the study area. Faults labeled as F1-F4 are strike-slip faults. Other faults are normal faults. "+" and "_" indicate foot wall and hanging wall of normal faults, respectively.

basins (Figs. 14(c), 16). One of these faults (F1) along the shelf edge of the study area is clearly observable on the seismic profiles (Figs. 9, 11, 12), with its deformation effects on the basin deposits at the south of the Büyükada Island (Fig. 11). This profile shows that layers of basin deposits are uplifted in the fault zone, indicating that Fault F1 forms a positive flower structure in this area. On another profile to the west of the Prince Islands, a ridge of basement rises over the sea floor (Fig. 9). Two small islands, Sivriada and Yassiada, on the shelf edge (Fig. 6(b)) are sub-aerial portions of this ridge. Some faults forming flower structures at the northern side and a vertical fault on the southern side of the ridge are also observed (Fig. 9). Sediments on both sides onlap on this ridge. Onlapped sediments seem to be tilted toward the opposite sides along the ridge axis, indicating that the ridge has been uplifted. All of this evidence indicates that the faults on both sides of the ridge form another positive flower structure (F1) at the shelf edge, causing uplift of the ridge on the sea floor (Fig. 9). Another fault 


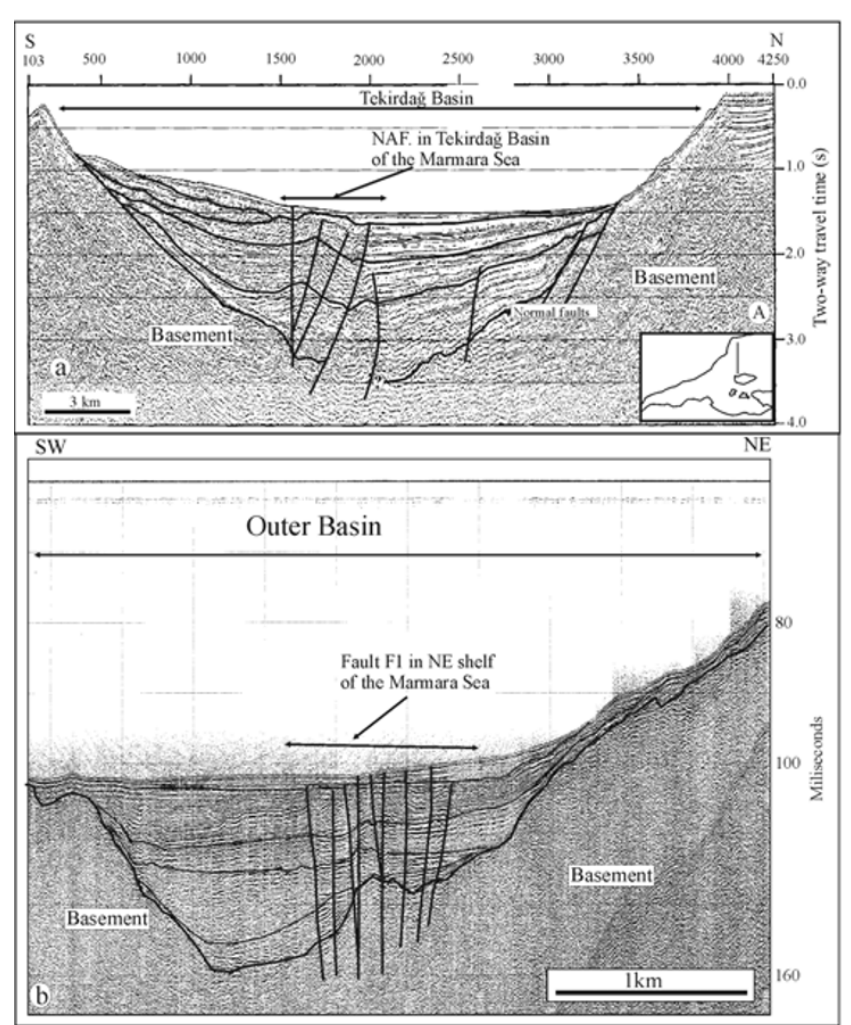

Fig. 17. (a) An interpreted seismic profile from the Tekirdag Basin of the Marmara Trough (from Gökaşan et al., 2003). On this profile, some normal faults are seen on the northern slope of the basin. However, a strike-slip fault, which was interpreted by previous studies as the current rupture of the NS-NAF (Okay et al., 1999, 2000; İmren et al., 2001; Le Pichon et al., 2001; Gökaşan et al., 2003), is observed at the center of the basin. (b) A part of a seismic profile in the study area (inset of Fig. 11). F1 which also appears at the center of the basin indicates a remarkable similarity on both faults, and NS-NAF and F1 indicate a relationship between the faults.

(F1 on Fig. 12) is observed at the shelf edge. Since these faults are following the direction of the NW-SE-oriented Lineament 1 on the sea floor (Fig. 6(b)), Lineament 1 is interpreted to be the surface rupture of a NW-SE-oriented strike-slip fault (Fault F1) lying on the shelf area from the south of the Central Ridge to the Küçükçekmece Lagoon (Fig. 16).

Two paleo-river valleys can be seen on a profile from the western portion of the Inner Basin (Fig. 10); these possibly flowed during the last glacial maximum when the sealevel of the Marmara Sea was $90 \mathrm{~m}$ lower than it is at the present time (Smith et al., 1995) and were subsequently filled with recent sediments when the sea level rose after the last glacial maximum. Recent sediments and the sea floor seem to have been deformed by faults on the central axes of the valleys (Fig. 10). The geometries of these faults indicate the existence of flower structures of two strike-slip faults: faults F2 and F3. Strike-slip faults on a profile from the eastern part of the Inner Basin are interpreted to be the eastern extension of the faults F2 and F3 (Fig. 8). These faults locate on the NW-SE-oriented lineaments on the basement morphology (Fig. 14(c)). Other strike-slip faults geographically locating to the north of the Fault F1 at the Outer Basin mostly coincide with Lineament 2 on the sea floor

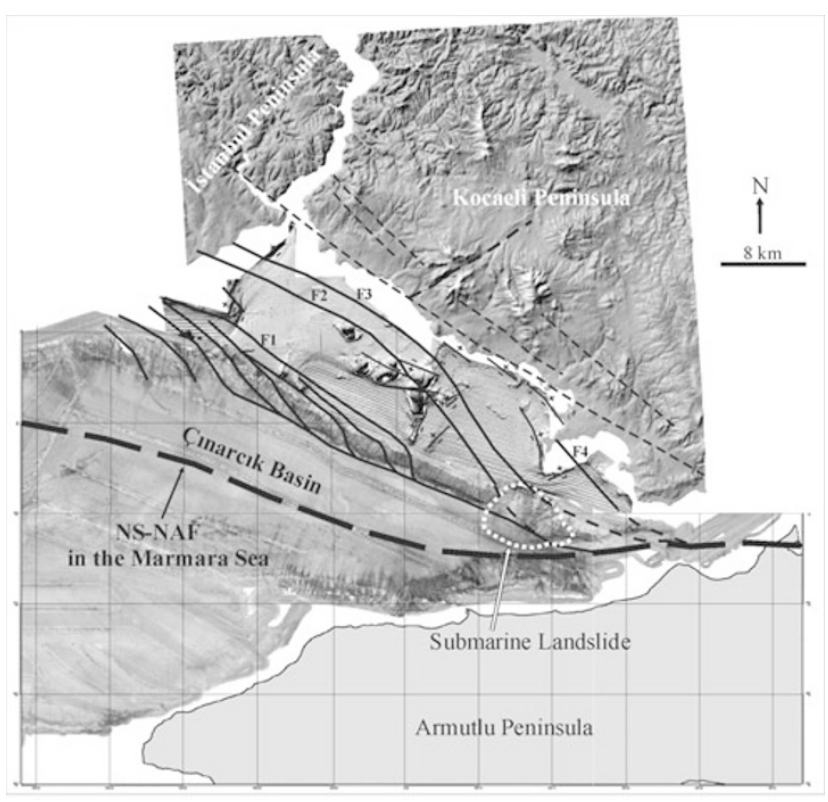

Fig. 18. Secondary fault activity and their relationship with the NS-NAF in the eastern Marmara Sea. Bold-dashed lines at the center of the Çınarcık Basin indicate the Northern Segment of the North Anatolian Fault (NS-NAF). Thin-dashed lines on land show the lineaments on the Kocaeli and İstanbul Peninsulas. Dashed circle indicates the area of a submarine landslide at the northern slope of the Çınarcık Basin, and the black line is the NS-NAF. See Fig. 16 for explanation of the secondary faults on the shelf area.

(Figs. 11-13). These are interpreted to be the eastern extension of the faults F2 and F3 along the Outer Basin. A creek on Büyükada Island and a buried valley on the north of Büyükada Island are interpreted to be the morphologic evidence of faults F2 and F3 passing through the Princes Island Ridge (inset 2 of Fig. 6(a), Fig. 14(c)). Thus, the wider depression on the sea floor represented by Lineament 2 should be controlled by two NW-SE strike-slip faults: F2 and F3 (Fig. 16). Another strike-slip fault (F4) appearing in Tuzla Bay also coincides with Lineament 3 on the sea floor (Figs. 6(b), 7, 16). Thus, Lineament 3 is also interpreted to be another NW-SE-oriented strike-slip fault: F4.

\section{Discussion and Conclusion}

Seismic data indicate that NNE-SSW-oriented normal faults control the basin-ridge morphology of the basement upper surface in the study area. The thickness of the deposits increases toward these faults, indicating they are syndepositional structures. Thus, the normal faults in the study area are responsible for the lowering of the Upper MiocenePliocene erosional surface and for the surface becoming a substratum for the Plio-Quaternary deposits. These faults must have been activated during the Plio-Quaternary period since they are post-erosional structures in the region. The faults, observed in previous studies delimiting the Strait of İstanbul and the Kocaeli and İstanbul Peninsulas (Alavi et al., 1989; Yılmaz and Sakınç, 1990; Oktay and Sakınç, 1991; Gökaşan et al., 1997; Demirbağ et al., 1999; Oktay et al., 2002; Gökaşan et al., 2005a, b) should be the equivalent structures of the normal faults observed in this study. Gökaşan et al. (1997) suggested that the Strait of İstanbul has been tectonically evolved from a river valley. The pro- 
posal of these authors is that during tectonic evolution, the initial river valley became a NNE-SSW-directed graben. Oktay et al. (2002) suggested that the NNE-SSW-oriented faults forming the strait were produced by a clockwise rotation of the İstanbul and Kocaeli Peninsulas between the dextral NS-NAF and a hypothetical dextral fault to the north following the Black Sea coasts of the peninsulas. Thus, the NNE-SSW-oriented sub-basins in the study area may have formed simultaneously with the genesis of the Strait of İstanbul following the erosional phase in the region. On the other hand, strike-slip faults cut through the basin and ridge system in the study area. These faults cut the basin fill of the grabens without resulting in any variations in thickness, suggesting that they are post-depositional faults in the area. The relationship between the NNE-SSW- and the NW-SEdirected faults is clearly visible on a seismic profile from the east of the Büyükada Island (Fig. 11, inset 1 of Fig. 14(c)), where thick sedimentary deposits characterized by a parallel reflection configuration are observed in a local depression delimited by normal faults between the Büyükada Island and a buried ridge located at the shelf edge. The normal fault at the southern boundary of the depression seems to control the formation of the basin since the thickness of the layers of the deposits increase toward this fault (inset of Fig. 11), suggesting that it is a syn-depositional structure. On the other hand, a strike-slip fault is observed at the central axis of the basin (Fault F1) which cuts whole sediments and the sea floor. Sediments in the fault zone rise without any thickness variations, showing that this strikeslip fault is younger than the deposits in the basin and postdate normal faulting (Fig. 11). These results are compatible with the interpretation regarding the lineaments on the basement morphology that the NW-SE-oriented lineaments cut and slightly dislocate the slopes of the sub-basins (insets 1 and 2 of Fig. 14(c)), which are controlled by the NNESSW-directed lineaments. Gökaşan et al. (1997) argued further that the NNE-SSW-oriented graben of the Strait of İstanbul gained its present zig-zag morphology by offsets on NW-SE- and NE-SW-oriented cross-cutting strike-slip faults. These faults may be structures that are similar to the NW-SE-oriented faults observed in this study.

Recent studies concerning the Marmara Sea reveal that the normal faults forming the Marmara Sea Basin are mostly inactive at present. However, the active segment of the NAF (NS-NAF) unconformably cuts the basins and ridges in the Marmara Trough along their central axis (İmren et al., 2001; Le Pichon et al., 2001; Gökaşan et al., 2001, 2002, 2003; Gazioğlu et al., 2002; Kuşçu et al., 2002; Demirbağ et al., 2003; Rangin et al., 2004; Şengör et al., 2004). These two different fault systems are clearly seen on a seismic profile from the Tekirdağ (Western) Basin (Gökaşan et al., 2003; Fig. 17(a)). Normal faults locate on both sides of the basin; these are mostly inactive at the present time. On the other hand, the NS-NAF, which deforms initially parallel bedded sediments, appears on the central axis of the basin. No thickness variation was observed along the NS-NAF, indicating that most of the deposits in the Marmara Trough pre-date the evolution of the NS-NAF (Gökaşan et al., 2003). İmren et al. (2001) and Le Pichon et al. (2001) suggested that the NS-NAF has been active since $200 \mathrm{ka}$ BP in the Marmara Sea. Fault F1 seems to have characteristics that resemble those of the NS-NAF in the Marmara Sea (inset of Fig. 11, Fig. 17(b)). This fault is the post-depositional structure for the sediments of the basin. These similarities indicate that the evolution of the Fault F1 may be related to the NS-NAF in the Marmara Sea, and this possible relationship may be supported by the morphology of the sea floor (Fig. 18). Fault F1 aligns along a NW-SE-oriented displacement zone at the northern slope of the Çınarcık Basin (Gökaşan et al., 2003; Fig. 18). At the northwestern side, Fault F1 also overlaps with a major fault controlling the eastern shoreline of the Küçükçekmece Lagoon (Gökaşan et al., 2002; Oktay et al., 2002; Fault F2 of their study). Gökaşan et al. (2002) suggested that the displacement on the shoreline around the Küçükçekmece Lagoon is more than $3 \mathrm{~km}$ in an NW direction. Thus, Fault F1 may be interpreted as being a fault that locates at the north of the principle deformation zone of the NS-NAF. Other strike-slip faults observed on the shelf area (faults F2, F3, and F4) also reach the shelf edge. These faults are supposed to have merged with the NS-NAF at the shelf edge in a similar manner to that of the Fault F1 (Fig. 18). However, the relationship between these faults and the NS-NAF can not be observed since a large submarine landslide has occurred on that slope (Fig. 18). Although the faults on the northern shelf join the NS-NAF, they can not be the main faults of the NAF since GPS results clearly indicate that the principle slip motion follows the fault passing through the Marmara Trough (McClusky et al., 2000; Fig. 18). Thus, the faults on the northern shelf should be secondary faults of the NAF in the Marmara Sea.

Several fault systems have developed along the Paleozoic-Mesozoic rocks of the İstanbul and Kocaeli Peninsulas that lie in different directions. The faults observed in this study may be these faults reactivated by the NS-NAF. Seismic evidence of a NW-SE-oriented strikeslip fault zone (Thrace Fault Zone) in Thrace was proposed by Perinçek (1991). Along the northern portion of Thrace, this fault is presently inactive since it was cut by the Pliocene-aged erosion surface. However, this fault deforms the erosion surface near the Marmara Sea coast of Thrace, indicating that it has been active near the Marmara Sea coast, possibly because the Thrace Fault Zone has been reactivated by the stress regime generated by the NAF around the Marmara Sea (Perinçek, 1991). Thus, faults in the study area may be the eastern members of the Thrace Fault Zone. Although the effects of these faults reach the sea floor, seismological data show very limited earthquake activity along the Istanbul and Kocaeli Peninsulas and on the northern shelf of the Marmara Sea. Taken together, these data indicate that seismic energy is mostly discharged by the principle fault zone of the NAF (NS-NAF) in the Marmara Sea (Fig. 18). Several large earthquakes have occurred in the Marmara Sea along this fault zone. However, a small amount of the energy accumulated along the neighboring areas of the NAF could be discharged by the secondary faults existing in adjacent areas, such as faults F1, F2, F3, and F4 on the NE shelf of the Marmara Sea. Since the areas around the NAF have a low level of seismic energy, earthquakes should occur with longer periods than 
those on the NS-NAF. Therefore, since earthquake periods of the secondary faults are possibly longer than the instrumental period of seismological records, seismic activity is lower in these areas. From this point of view, it is concluded that the secondary faults along the main rupture of the NAF are not inactive today, that these faults actually have low activity, and that they may be able to produce earthquakes in future. Two earthquake events $\left(M_{w}=3.7\right.$ and $\left.M_{w}=4.2\right)$ to the north of the NAF in the Eastern Marmara Sea (Pinar et al., 2003; Fig. 2(b)) prove this result.

Acknowledgments. This study was supported by the Research Foundation of Istanbul University grant 75/15052003. We would like to thank the Turkish Navy, the Department of Navigation, Hydrography and Oceanography, and the personnel of the R/V T. C. G. Çubuklu, and R/V T. C. G. Çeşme for their enthusiasm and care during the seismic data collection.

\section{References}

Aksu, A. E., T. J. Calon, and R. N. Hicott, Anatomy of the North Anatolian Fault Zone in the Marmara Sea, Western Turkey: extensional basins above a continental transform, GSA Today, 10(6), 3-7, 2000.

Alavi, S. N., M. Okyar, and K. Timur, Late Quaternary Sedimentation in the Strait of Bosphorus: High resolution Seismic Profiling, Mar. Geol., 89, 185-205, 1989.

Armijo, R., B. Meyer, A. Hubert, and A. Barka, Westward propogation of the North Anatolian Fault into the northern Aegean: timing and kinematics, Geology, 27, 267-270, 1999.

Armijo, R., B. Meyer, S. Navarro, G. King, and A. Barka, Asymmetric slip partitioning in the Sea of Marmara pull-apart: a clue to propagation process of the North Anatolian Fault, Terra Nova, 14, 80-86, 2002.

Armijo, R., N. Pondard, B. Meyer, G. Uçarkuş, B. Mercier de Le'pinay, J. Malavieille, S. Dominguez, M. Gustcher, S. Schmidt, C. Beck, N. Çağatay, Z. Çakır, C. İmren, K. Eriş, B. Natalin, S. Özalaybey, L. Tolun, I. Lefe'vre, L. Seeber, L. Gasperini, C. Rangin, O. Emre, and K. Sarikavak, Submarine fault scarps in the Sea of Marmara pull-apart (North Anatolian Fault): Implications for seismic hazard in Istanbul, Geochem. Geophy. Geosyst., 6(6), Q06009, doi:10.1029/ 2004GC000896, 2005.

Barka, A. A., The North Anatolian fault zone, Ann Tectonics Spec Issue, 6, 164-195, 1992.

Barka, A., The 17 August 1999 Izmit earthquake, Science, 285, 1858-59, 1999.

Barka, A. A. and K. Kadinsky-Cade, Strike-slip fault geometry in Turkey and its influence on earthquake activity, Tectonics, 7, 663-684, 1988.

Carton, H., Structure of the Çınarcık Basin (eastern Marmara Sea) from densely-spaced multi-channel reflection profiles, Lithos Science Report, pp. 69-76, Bullard Lab., Univ. of Cambridge, Cambridge, UK, 2003.

Cvijic, J., Grundlinien der Geographie und Geologie von Mazedonien und Altserbien, Petermans Mitteilungen Erganzungsheft I(162), Gotha, 1908.

Demirbağ, E., E. Gökaşan, F. Y. Oktay, M. Şimşek, and H. Yüce, The last sea level changes in the Black Sea: evidence from the seismic data, Mar. Geol., 157, 249-265, 1999.

Demirbağ, E., C. Rangin, X. Le Pichon, and A. M. C. Şengör, Investigation of the tectonics of the Main Marmara Fault by means of deep towed seismic data, Tectonophysics, 361, 1-19, 2003.

Elmas, A., Late Cenozoic tectonics and stratigraphy of northwestern Anatolia: the effects of the North Anatolian Fault to the region, Int. J. Earth Sci., 92, 380-396, 2003.

Emre, O., T. Erkal, A. Tchepalyga, N. Kazancı, M. Keçer, and E. Unay, Doğu Marmara bölgesinin Neojen-Kuvaterner'deki evrimi, MTA Dergisi, 120, 223-258, 1988.

Erinç, S., Jeomorfoloji I, Der Press No: 284, İstanbul, 614 pp., 2000.

Eroskay, O. and S. Kale, İstanbul Boğazı tüp tünel geçişi güzergahında jeoteknik bulgular, Mühendislik Jeolojisi Bülteni, 8, 2-7, 1986.

Gazioğlu, C., E. Gökaşan, O. Algan, Z. Y. Yücel, B. Tok, and E. Doğan, Morphologic features of the Marmara Sea from multi-beam data, Mar. Geol., 190(1-2), 333-356, 2002.

Gökaşan, E., E. Demirbağ, F. Y. Oktay, B. Ecevitoğlu, M. Şimşek, and H. Yüce, On the origin of the Bosphorus, Mar Geol., 140, 183-199, 1997. Gökaşan, E., B. Alpar, C. Gazioğlu, Z. Y. Yücel, B. Tok, E. Doğan, and C.
Güneysu, Active tectonics of the Izmit Gulf (NE Marmara Sea): from high resolution seismic and multi-beam bathymetry data, Mar. Geol., 175(1-4), 271-294, 2001.

Gökaşan, E., C. Gazioğlu, B. Alpar, Z. Y. Yücel, S. Ersoy, O. Gündoğdu, C. Yaltırak, and B. Tok, Evidences of NW extension of the North Anatolian Fault Zone in the Marmara Sea; a new approach to the 17 August 1999 Marmara Sea earthquake, Geo-Mar. Lett., 21, 183-199, 2002.

Gökaşan, E., T. Ustaömer, C. Gazioğlu, Z. Y. Yücel, K. Öztürk, H. Tur, B. Ecevitoğlu, and B. Tok, Morpho-tectonic evolution of the Marmara Sea inferred from multi-beam bathymetric and seismic data, Geo-Mar. Lett., 23/1, 19-33, 2003.

Gökaşan, E., H. Tur, B. Ecevitoğlu, T. Görüm, A. Türker, B. Tok, F. Çağlak, H. Birkan, and M. Şimşek, Evidence and implications of massive erosion along the Strait of İstanbul (Bosphorus), Geo-Mar. Lett., 25/5, 324-342, 2005a.

Gökaşan, E., O. Algan, H. Tur, E. Meriç, A. Türker, and M. Şimşek, Delta formation at the southern entrance of Istanbul Strait (Marmara Sea, Turkey): a new interpretation based on high-resolution seismic stratigraphy, Geo-Mar. Lett., 25/6, 370-377, 2005 b.

Gürbüz, C., M. Aktar, H. Eyidoğan, A. Cisternas, H. Haessler, A. Barka, M. Ergin, N. Türkelli, O. Polat, S. B. Ucer, S. Kuleli, S. Bariş, B. Kaypak, T. Bekler, E. Zor, F. Biçmen, and A. Yörük, The seismotectonics of the Marmara Region (Turkey): results from a microseismic experiment, Tectonophysics, 316, 1-17, 2000.

İmren, C., X. Le Pichon, C. Rangin, E. Demirbağ, B. Ecevitoğlu, and N. Görür, The North Anatolian Fault within the Sea of Marmara: a new evaluation based on multichannel seismic and multi-beam data, Earth Planet Sci. Lett., 186, 143-158, 2001.

Ketin, İ., Uber die tektonisch-mechanischen Folgerungen aus der grossen anatolischen Erdbeben des letzten Dezenniums, Geol. Rundsch., 36, 7783, 1948 .

Ketin, İ., Relations between general tectonic features and the main earthquake regions in Turkey, MTA Bull., 71, 129-134, 1968.

Kuşçu, Y., M. Okamura, H. Matsuoka, and Y. Awata, Active faults in the Gulf of Izmit on the North Anatolian Fault, NW Turkey: a high resolution shallow seismic study, Mar. Geol., 190(1-2), 421-433, 2002.

Le Pichon, X., A. M. C. Şengör, E. Demirbağ, C. Rangin, C. İmren, R. Armijo, N. Görür, N. Cağatay, B. Mercier de Lepinay, B. Meyer, R. Saatcilar, and B. Tok, The active main Marmara Fault, Earth Planet Sci. Lett., 192, 595-616, 2001.

McClusky, S., S. Balassanian, A. Barka, and the others, Global Positioning system constraints on plate kinematics and dynamics in the Eastern Mediterranean and Caucasus, J. Geophys. Res., 105, 5695-5719, 2000.

Okay, A., E. Demirbağ, H. Kurt, N. Okay, and I. Kuşçu, An active, deep marine strike-slip basin along the North Anatolian fault in Turkey, Tectonics, 18(1), 129-147, 1999.

Okay, A. I., A. Kaşlılar-Özcan, C. İmren, A. Boztepe-Güney, E. Demirbağ, and I. Kuşçu, Active faults and evolving stike-slip basins in the Marmara Sea, northwest Turkey: a multichannel seismic reflection study, Tectonophysics, 321, 189-218, 2000.

Oktay, F. Y. and M. Sakınç, The Late Quaternary Tectonics of the Istanbul Graben and the Origin of the Bosphorus, Terra Abstr. EUG. 6. Strasbourg 3,1, 351, 1991.

Oktay, F. Y., E. Gökaşan, M. Sakıinç, C. Yaltırak, C. İmren, and E. Demirbağ, The effect of North Anatolian Fault Zone to the latest connection between Black Sea and Sea of Marmara, Mar. Geol., 190(1-2), 367-382, 2002.

Orgülü, G. and M. Aktar, Regional moment tensor inversion for strong aftershocks of the August 17, 1999, Izmit Earthquake $\left(M_{w}=7.4\right)$, Geophys. Res. Lett., 28(2), 371-374, 2001.

Pamir, H. N., On the problem about the formation of the Strait of Istanbul, MTA Bull., 3-4, 61-69, 1938 (in Turkish).

Perinçek, D., Possible strand of the North Anatolian Fault Zone in the Thrace Basin, Turkey-an interpretation, AAPG Bull., 75, 241-257, 1991.

Pinar, A., K. Kuge, and Y. Honkura, Moment tensor inversion of recent small to moderate sized earthquakes: implications for seismic hazard on active tectonics beneath the Sea of Marmara, Geophys. J. Int., 153, 133-145, 2003.

Rangin, C., X. Le Pichon, E. Demirbağ, and C. İmren, Strain localization in the Sea of Marmara: Propagation of the North Anatolian Fault in a now inactive pull-apart, Tectonics, 23, TC2014, doi, 10.1029/2002TC001437, 2004.

Şengör, A. M. C., The North Anatolian Transform Fault; its age offset and tectonic significance, J. Geol. Soc. Lond., 136, 269-282, 1979.

Şengör, A. M. C., O. Tüysüz, C. İmren, M. Sakıinç, H. Eyidoğan, N. Görür, X. Le Pichon, and C. Rangin, The North Anatolian Fault: A New Look, 
Annu. Rev. Earth Planet. Sci., 33, 1-75, 2004.

Seymen, I., Geology of the Izmit Gulf region (NW Turkey), in Quaternary Sequence in the Gulf of Izmit, edited by E. Meric, Turkish Navy Pres, Istanbul, 1-23, 1995 (in Turkish).

Smith, A. D., T. Taymaz, F. Oktay, H. Yüce, B. Alpar, H. Başaran, J. A. Jackson, S. Kar, M. Şimşek, High-resolution seismic profiling in the Sea of Marmara (Northwest Turkey): Late Quaternary sedimentation and sea-level changes, Geol. Soc. Am. Bull., 107, 923-936, 1995.

Uluğ, A., E. Özel, and G. Çiftçi, İstanbul Boğazı'nda Sismik Çalışmalar, Jeofizik Dergisi, 130-144, 1987.

Yaltırak, C., Tectonic evolution of the Marmara Sea and its surroundings, Mar. Geol., 190(1-2), 493-529, 2002.

Yaltırak, C., M. Sakınç, A. E. Aksu, R. N. Hiscott, B. Galleb, and U. B. Ulgen, Late Pleistocene uplift history along the southwestern Marmara Sea determined from raised coastal deposits and global sea-level variations, Mar. Geol., 190(1-2), 283-305, 2002.
Yilmaz, Y., Morphotectonic evolution of the Southern Black Sea Region and the Bosphorus Channel, in The Black Sea Flood Question: changes in the coastline, climate, and human settlement, edited by V. YankoHombach, NATO Science Series IV-Earth and Environmental Sciences, 2006 (in press).

Yılmaz, Y. and M. Sakınç, İstanbul Boğazı'nın Jeolojik Gelişimi Üzerine Düsünceler, İstanbul Boğazı Güneyi ve Haliç'in Geç Kuvaterner (Holosen) Dip Tortullarl, edited by E. Meriş and İ. Yayınları, 99-105, 1990.

Yiğitbaş, E., A. Elmas, A. Sefunc, and N. Özer, Major neotectonic features of eastern Marmara Region, Turkey: development of the Adapazar1Karasu corridor and its tectonic significance, Geol. J., 39, 179-198, 2004

H. Tur (e-mail: tur@istanbul.edu.tr) 